fundamental. For example, how can dynamic socio-ecological feedback loops become integrated within dynamic financial markets? How can we measure the effects of trillions of dollars of investment on natural capital stocks or ecosystem services? How can financial governance models make these interconnections possible? And we need to experiment with new organizations that better connect financial markets to science and societies.

One such example is the Resilience Alliance, an international research network of scientists and practitioners working on sustainability. Their Connectors Group is trying to establish more-explicit links with the business world not an easy task given the differences in career focus, social norms and conventional meeting places. Yet scientists can be inspired by the chapter on civil society. Non-governmental organizations influence capital markets through active capital campaigns, including shareholder activism, partnerships with powerful institutional investors and formal investor briefings.

Sustainable Investing is a good read for managing your portfolio. But it remains to be seen if Nature will be read by investment analysts. Gail Whiteman is associate professor and director of the Sustainability and Climate Research Centre, Rotterdam School of Management, Erasmus University, 3062 PA Rotterdam, the Netherlands. e-mail:gwhiteman@rsm.nl

\title{
In search of adventure
}

\begin{abstract}
Most scientists have tried to explain their work to inquisitive relatives or acquaintances. Whether one studies salamander biology, glacial moraines or dark energy, one inevitably faces someone who is convinced that a life devoted to understanding nature is no vocation for a grown person and is merely an escape from the 'real world'. The string theorist and author, Brian Greene, has argued that these misperceptions are derived from how science is taught and communicated to the public. His prescription is that scientists need to convey the breathtaking vistas opened up by scientific inquiry and teach science for what it is: one of humanity's great adventure stories. Evolutionary biologist Sean Carroll's new book, Remarkable Creatures, fills this important niche.
\end{abstract}

Carroll tells the story of evolution through the adventures that lie behind its great discoveries. With skill as a storyteller, and a passion for his subject, Carroll deftly describes the great expeditions and people behind 13 major discoveries in natural history over the past 200 years. He imparts an infectious enthusiasm for the act of discovery, with all the risks, failures, dead ends and ultimate successes that expeditionary work

Remarkable Creatures: Epic Adventures in
the Search for the Origin of Species
by Sean B. Carroll
Houghton Mifflin Harcourt: 2009 .
352 pp. $\$ 26$
often involves. As fast-paced as a detective story, the book is a primer on the joy of being an evolutionary biologist, written by one of our best modern practitioners.

Carroll reveals the challenges and rewards of venturing into the unknown. He begins his tour in 1800 , in an age when vast stretches of

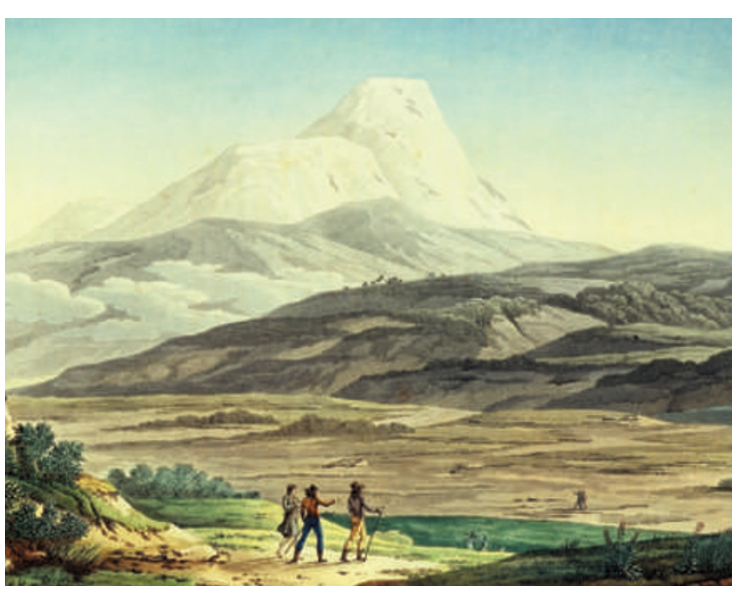

Ecuador's unexplored terrain thrilled the nineteenth-century naturalist and explorer Alexander von Humboldt.

Earth were unexplored wilderness, and much of the flora and fauna was unknown to western science. His first tale, that of the naturalist and explorer Alexander von Humboldt, opens with the combination of enthusiasm, hardship and adventure that pervades the narrative of later chapters. Venturing into the forests of South America, Humboldt exclaims in a letter to his brother: "What trees! Coconut trees, fifty to sixty feet high ... We rush around like the demented; in the first three days we were unable to classify anything...." Like Humboldt, each of the scientists in Carroll's book was the first one to see a new fossil, species or historical connection. And each shared Humboldt's excitement.

The first part of the book describes the travel adventures of Charles Darwin, Alfred Russel Wallace and Henry Walter Bates. Lacing each tale with anecdotes of success and failure, Carroll conveys the sense that real people with real aspirations, fears and enthusiasm endured years in jungles and on ships to come up with ideas that would ultimately change the way scientists view the natural world. Next come stories of major fossil discoveries, showing how exploring the rocks of the world can reveal the history of life. He uses as his examples Eugène Dubois's discovery of the Java Man fossils, the Cambrian radiation of animal phyla, the origin of birds, the impact theory for mass extinction, and the fishapod, Tiktaalik, including my own work with Ted Daeschler and Farish A. Jenkins. The final grouping looks at human origins and bridges from the fossil record to the molecular one, first revealed by Linus Pauling and Emile Zukerkandl, and later by Allan Wilson, Vincent Sarich, Mark Stoneking and Svante Pääbo. This shift, from expeditions revealing new fossils to laboratory adventures recovering ancient DNA, reflects a bridge to our current approach, one that integrates data from fields as diverse as geology and molecular biology to explain evolutionary history.

In reading Remarkable Creatures, one could feel a sense of loss that the days of great adventure are no more. We live in an age in which almost every region of Earth has been mapped and every species known is being documented with its own web page in the Encyclopedia of Life. It is easy to think that the days when a naturalist such as Humboldt could describe themselves as demented with the joy of seeing a new vista for the first time are over.

But unexplored vistas still exist, from the countless new species of microbes that dwell in every clump of dirt and every inch of our guts to the deepest reaches of space revealed by telescopes and probes. Indeed, in the cast of scientists manning the Mars rovers at NASA mission control, we find a room full of Humboldts, exploring a new world and giddy with each patch of Mars that is seen for the first time. These emotions are among the universals of our vocation, and there are few better introductions to them than Carroll's book. Remarkable Creatures is the book to give those inquisitive relatives, or even more important for our society's future, their kids.

Neil Shubin is professor of anatomy at the University of Chicago and author of Your Inner Fish: A Journey into the 3.5 Billion Year History of the Human Body.

e-mail: nshubin@uchicago.edu 